\title{
Evaluation of different lactic acid bacterial strains for probiotic characteristics
}

\author{
B. Srinu. ${ }^{1}$, T. Madhava Rao ${ }^{1}$, P. V. Mallikarjuna Reddy ${ }^{2}$ and K. Kondal Reddy ${ }^{2}$ \\ 1. Department of Veterinary Public Health, College of Veterinary Science, Rajendranagar, Hyderabad, \\ Andhra Pradesh, India; 2. Department of Livestock Products Technology, College of Veterinary Science, \\ Rajendranagar, Hyderabad, Andhra Pradesh, India \\ Corresponding author: B. Srinu, email: beesamsrinu@gmail.com \\ Received: 25-05-2013, Revised: 18-07-2013, Accepted: 19-07-2013, Published online: 27-08-2013
}

doi: $10.14202 /$ vetworld.2013.785-788

How to cite this article: Srinu B, Madhava Rao T, Mallikarjuna Reddy PV and Kondal Reddy K (2013) Evaluation of different lactic acid bacterial strains for probiotic characteristics, Veterinary World 6(10): 785-788.

\begin{abstract}
Objective: The objective of the present study was to collect different Lactic acid bacterial strains from culture collection centers and screen their functional probiotic characteristics such as acid tolerance, bile tolerance, antibacterial activity and antibiotic sensitivity for their commercial use.

Materials and Methods: Acid and bile tolerence of selected LAB(Lactic acid bacteria) was determined. The antibiotic resistance of Lactobacillus species was assessed using different antibiotic discs on de Mann Rogosa Sharpe broth (MRS) agar plates seeded with the test probiotic organism. The antibacterial activity of LAB was assessed by using well diffusion method.

Results: Among the six probiotic strains tested, all showed good survivability at high bile salt concentration $(0.3$ to $2.0 \%$ oxgall) and good growth at a low $\mathrm{pH}$ of 1.5 to 3.5. These probiotic species showed good survival abilities in acidic $\mathrm{pH}$ of 2.0 to 3.5 except Lactobacillus delbrueckii subspp. bulgaricus 281 which did not grown at $\mathrm{pH}$ of 2.0. Lactobacillus fermentum 141 was able to grow even at $\mathrm{pH}$ of 1.5 also. Among the six lactic acid species, Lactobacillus fermentum 141 (except Tetracycline), Lactobacillus delbrueckii subspp. Bulgaricus 281 except (Cefpodoxime) and all other LAB were resistant to all the antibiotics tested (Ampicillin, Nalidixic acid, Ciprofloxacin ,Co-Trimoxazole, Gentamicin and Cefpodoxime). All these probiotic organisms were screened for their in vitro inhibition ability against pathogenic microorganisms namely, E.coli ATCC (American type culture collection centre), Pseudomonas aeruginosa, Salmonella paratyphi, Staphylococcus aureus. Lactobacillus delbrueckii subspp. bulgaricus 281, Lactobacillus casei 297 and Lactobacillus fermentum 141 inhibited the growth of all the pathogenic bacteria used in the study.
\end{abstract}

Conclusion: The study indicated Lactobacillus fermentum 141 and Lactobacillus casei 297 as potential functional probiotics for future in vivo studies for commercialization in the food industry.

Key words: in vitro studies, lactic acid bacteria, probiotics characteristics.

\section{I ntroduction}

The gut microbiota is made up of diverse and complex microbial communities including bacteria, fungi and protozoa. This micro- biota plays a key role in the host overall health [1] through its metabolic activities and physiological regulation such as promotion of nutrient absorption, synthesis of bioactive compounds, improvement of intestinal barrier function, motility and resistance to pathogens or modulation of the immune system. Alteration of the microbiota may cause some direct or indirect digestive pathologies like infectious diseases and chronic inflammation [2, 3] metabolic disorders [4] or atopic diseases [5]. There is lot of awareness among people about use of probiotics in place of antibiotics during the last decade but there has been a lot of confusion due to increased influx of probiotic foods with several strains of LAB in Indian market. Most of the strains of lactic acid bacteria used

Copyright: The authors. This article is an open access article licensed under the terms of the Creative Commons Attribution License (http://creativecommons.org/licenses/by/2.0) which permits unrestricted use, distribution and reproduction in any medium, provided the work is properly cited. as probiotics in foods have very similar physiological properties and nutritional requirements and grow under similar environmental conditions. It is necessary to identify suitable LAB's with good characteristics of probiotics to promote Public Health and to avoid confusion. Identifying probiotic characteristics of these bacterial strains by in vitro studies forms the basis for selection of functional probiotics for commercial use.

Therefore, the present study was undertaken to screen and compare the functional probiotic properties of known strains of lactic acid bacteria.

\section{Materials and Methods}

Experimental design: Six Lactic acid bacterial strains were evaluated for their probiotic characteristics namely acid tolerance, tolerance to bile salts, antagonistic activity against different food borne pathogens and antibiotic sensitivity.

Lactic acid bacterial strains: The lactic acid bacterial strains namely, Lactobacillus fermentum 141, Lactobacillus casei 297, Lactobacillus fermentum 156, Lactobacillus rhamnosus 18, Lactobacillus delbruckii 
Table-1. Survivability of Lactobacillus species at different $\mathrm{pH}$ levels in MRS broth.

\begin{tabular}{llllll}
\hline Name of the probiotic organism & \multicolumn{5}{c}{$\mathbf{p H}$} \\
\cline { 2 - 6 } & $\mathbf{1 . 5}$ & $\mathbf{2 . 0}$ & $\mathbf{2 . 5}$ & $\mathbf{3 . 0}$ & $\mathbf{3 . 5}$ \\
\hline Lactobacillus fermentum 141 & $+\mathrm{ve}$ & $+\mathrm{ve}$ & $+\mathrm{ve}$ & $+\mathrm{ve}$ & $+\mathrm{ve}$ \\
Lactobacillus fermentum 156 & $-\mathrm{ve}$ & $+\mathrm{ve}$ & $+\mathrm{ve}$ & $+\mathrm{ve}$ & $+\mathrm{ve}$ \\
Lactobacillus rhamnosus 18 & $-\mathrm{ve}$ & $+\mathrm{ve}$ & $+\mathrm{ve}$ & $+\mathrm{ve}$ & $+\mathrm{ve}$ \\
Lactobacillus plantarum 20 & $-\mathrm{ve}$ & $+\mathrm{ve}$ & $+\mathrm{ve}$ & $+\mathrm{ve}$ & $+\mathrm{ve}$ \\
Lactobacillus delbrueckii subspp. bulgaricus 281 & $-\mathrm{ve}$ & $+\mathrm{ve}$ & $+\mathrm{ve}$ & $+\mathrm{ve}$ & $+\mathrm{ve}$ \\
Lactobacillus casei 297 & $-\mathrm{ve}$ & $+\mathrm{ve}$ & $+\mathrm{ve}$ & $+\mathrm{ve}$ & $+\mathrm{ve}$ \\
\hline
\end{tabular}

Note: -ve means no turbidity, + ve means turbidity present after incubation at $37^{\circ} \mathrm{C}$ for $48 \mathrm{~h}$.

Table-2. Absorbance values of MRS broth inoculated with Lactobacillus species at different oxgall concentration ( 0.3 to 2.0 $\%$ ) after incubation at $37^{\circ} \mathrm{C}$ for $24 \mathrm{~h}$.

\begin{tabular}{lllll}
\hline Name of the probiotic organism & \multicolumn{3}{c}{ Absorbance at $\mathbf{6 2 0} \mathbf{~ n m}$ by spectrophotometer } \\
\cline { 2 - 5 } & $\mathbf{0 . 3 \%}$ & $\mathbf{0 . 5 \%}$ & $\mathbf{1 . 0} \%$ & $\mathbf{2 . 0 \%}$ \\
\hline Lactobacillus fermentum 141 & 1.878 & 1.674 & 1.423 & 1.397 \\
Lactobacillus fermentum 156 & 1.769 & 1.564 & 1.453 & 1.276 \\
Lactobacillus rhamnosus 18 & 1.438 & 1.153 & 1.061 & 0.999 \\
Lactobacillus plantarum 20 & 1.540 & 1.239 & 1.101 & 0.95 \\
Lactobacillus delbrueckii subspp. bulgaricus 281 & 1.852 & 1.645 & 1.534 & 1.256 \\
Lactobacillus casei 297 & 1.487 & 1.365 & 1.187 & 1.027 \\
\hline
\end{tabular}

subspp bulgaricus 281 and Lactobacillus plantarum 20 were obtained from National Dairy Research Institute (NDRI, Karnal) to test their functional probiotic characteristics. Culture media were procured from Himedia Laboratories, India and prepared according to standard procedures. The lactic acid bacterial strains were sub-cultured three times before use in sterile de Mann Rogosa Sharpe broth (MRS) using 1\% inoculums and incubated at $37^{\circ} \mathrm{C}$ for $48 \mathrm{~h}$.

Acid and bile tolerance: Acid and bile tolerence of selected LAB was determined according to [6] method. The growth of LAB in MRS broth containing different concentrations of oxgall was measured by spectrophotometer at $620 \mathrm{~nm}$. The growth of LAB in MRS broth with different $\mathrm{pH}$ range (1.5, 2.0, 3.0 and 3.5was tested. The growth of LAB on MRS agar plate was used to designate as acid and bile salt tolerant.

Antibiotic sensitivity test: The antibiotic resistance of Lactobacillus species was assessed using different antibiotic discs on MRS agar plates seeded with the test probiotic organism. The antibiotic discs were placed on the surface of agar and the plates were kept at $4^{\circ} \mathrm{C}$ for $1 \mathrm{~h}$ for diffusion and then incubated at $37^{\circ} \mathrm{C}$ for $24 \mathrm{~h}$ according to [7]. Resistance was assessed against the different antibiotic discs namely Ampicillin $(10 \mathrm{mcg})$,

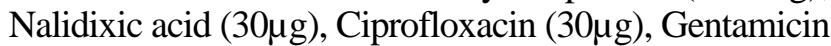
$(10 \mu \mathrm{g})$, Cefpodoxime $(10 \mu \mathrm{g})$, Co-Trimoxazole $(25 \mu \mathrm{g})$ and Tetracycline $(10 \mu \mathrm{g})$. The zone size $(\mathrm{mm})$ interpretative chart for antibiotics was measured according to Performance Standards for Antimicrobial Disk Susceptibility Tests as described by [8].

Antibacterial activity: A modified method described by [9] was used in which an overnight culture of pathogenic microorganisms namely. Staphylococcus aureus, Salmonella paratyphi B, Escherichia coli and Pseudomonas aeruginosa were grown in nutrient broth. A lawn of an indicator strain i.e., pathogenic organisms were made by spreading the cell suspension over the surface of MRS agar plates with a sterile cotton swab. The plates were allowed to dry and a sterile cork borer of diameter $7.0 \mathrm{~mm}$ was used to cut uniform wells in the agar plates. Each well was filled with $0.1 \mathrm{ml}$ of inoculums from MRS broth and incubated at $37^{\circ} \mathrm{C}$ for 36 to $48 \mathrm{~h}$. After incubation, the diameter $(\mathrm{mm})$ of the inhibition zone around the well was measured by [8] method.

\section{Results and Discussion}

Acid and bile tolerance: The bile and acid tolerance are important characteristics of lactic acid bacterial strains. Bile tolerance is required for bacterial growth in small intestine [10] and acid tolerance is required for the bacteria to survive passage through the stomach [11] as well as to survive in food [10]. All the selected Lactic acid bacterial strains showed good survival abilities in the tested acidic $\mathrm{pH}$ range $(1.5,2.0,3.0$ and 3.5) as shown in Table-1. Among all the strains tested except, Lactobacillus delbrueckii subspp. bulgaricus 281 did not grow at $\mathrm{pH} 2.0$ and these findings are in accordance with the reports of $[6,12,13,14$,$] .$

In the present study, it was observed that all the Lactic acid bacterial strains survived and tolerated bile salts (Oxgall) concentrations of 0.3 to $2.0 \%$ quite effectively. But a marginal decrease in the viability of all the strains was found when a bile salt concentration was increased from 0.3 to $2.0 \%$. Similar observations were also reported by [15]. The differences in the absorbance values of bile tolerance (at $620 \mathrm{~nm}$ ) between strains in the present study might be due to differences in their ability to grow and colonize and these findings are similar to the findings of [16] (Table-2). Among all the Lactobacillus spp., Lactobacillus fermentum 141 showed highest absorbance at $620 \mathrm{~nm}$ at different bile salt concentrations (0.3-2.0\%). Absorbance values are presented in the Table- 2 . 
Table-3. Lactobacillus species showing sensitivity/resistant with different antibiotics (zone of inhibition diameter in $\mathrm{mm}$ ) [24].

\begin{tabular}{|c|c|c|c|c|c|c|c|}
\hline Name of the probiotic organism & Ampicillin & Nalidixic acid & Ciprofloxicin & Cefpodoxime & Gentamicin & Co-Trimoxazole & Tetracycline \\
\hline $\begin{array}{l}\text { Lactobacillus fermentum } 141 \\
\text { Lactobacillus fermentum } 156 \\
\text { Lactobacillus rhamnosus } 18 \\
\text { Lactobacillus plantarum } 20 \\
\text { Lactobacillus delbrueckii subspp. } \\
\text { bulgaricus } 281\end{array}$ & $\begin{array}{l}13 \mathrm{~mm}(\mathrm{R}) \\
25 \mathrm{~mm}(\mathrm{~S}) \\
23 \mathrm{~mm}(\mathrm{~S}) \\
\mathrm{R} \\
11 \mathrm{~mm}(\mathrm{R})\end{array}$ & $\begin{array}{l}R \\
R \\
R \\
R \\
R\end{array}$ & $\begin{array}{l}20 \mathrm{~mm}(\mathrm{I}) \\
27 \mathrm{~mm}(\mathrm{~S}) \\
13 \mathrm{~mm}(\mathrm{R}) \\
12 \mathrm{~mm}(\mathrm{R}) \\
13 \mathrm{~mm}(\mathrm{R})\end{array}$ & $\begin{array}{l}\mathrm{R} \\
22 \mathrm{~mm}(\mathrm{~S}) \\
26 \mathrm{~mm}(\mathrm{~S}) \\
14 \mathrm{~mm} \text { ( }) \\
28 \mathrm{~mm}(\mathrm{~S})\end{array}$ & $\begin{array}{l}14 \mathrm{~mm}(\mathrm{I}) \\
\mathrm{R} \\
15 \mathrm{~mm}(\mathrm{~S}) \\
14 \mathrm{~mm}(\mathrm{I}) \\
10 \mathrm{~mm}(\mathrm{R})\end{array}$ & $\begin{array}{c}R \\
R \\
R \\
R \\
10 \mathrm{~mm}(\mathrm{R})\end{array}$ & $\begin{array}{l}25 \mathrm{~mm}(\mathrm{~S}) \\
\mathrm{R} \\
34 \mathrm{~mm}(\mathrm{~S}) \\
\mathrm{R} \\
18 \mathrm{~mm}(\mathrm{I})\end{array}$ \\
\hline Lactobacillus casei 297 & $\mathrm{R}$ & $\mathrm{R}$ & $\mathrm{R}$ & $\mathrm{R}$ & $\mathrm{R}$ & $\mathrm{R}$ & $\mathrm{R}$ \\
\hline
\end{tabular}

In brackets $\mathrm{R}=$ Resistant $\mathrm{S}=$ Sensitive, I=Intermediatory according to the performance standards for antimicrobial disc suspension tests [24].

Table-4. Antibacterial activity of Lactobacillus spp. against various pathogenic bacteria

\begin{tabular}{|c|c|c|c|c|}
\hline Name of the probiotic organism & S. aureus & Salmonella para-B & E.coli ATCC & Pseudomonas spp. \\
\hline Lactobacillus fermentum 141 & $15 \mathrm{~mm}$ & $19 \mathrm{~mm}$ & Resistant & $13 \mathrm{~mm}$ \\
\hline Lactobacillus fermentum 156 & Resistant & $14 \mathrm{~mm}$ & Resistant & $13 \mathrm{~mm}$ \\
\hline Lactobacillus rhamnosus 18 & Resistant & $15 \mathrm{~mm}$ & $17 \mathrm{~mm}$ & $12 \mathrm{~mm}$ \\
\hline Lactobacillus plantarum 20 & Resistant & $17 \mathrm{~mm}$ & $13 \mathrm{~mm}$ & Resistant \\
\hline Lactobacillus delbrueckii subspp. bulgaricus 281 & $17 \mathrm{~mm}$ & $16 \mathrm{~mm}$ & $16 \mathrm{~mm}$ & $15 \mathrm{~mm}$ \\
\hline Lactobacillus casei 297 & $16 \mathrm{~mm}$ & $20 \mathrm{~mm}$ & Resistant & $17 \mathrm{~mm}$ \\
\hline
\end{tabular}

Antibiotic sensitivity test: Among six Lactobacillus spp. tested, Lactobacillus fermentum 141 (except Tetracycline), Lactobacillus plantarum 20, Lactobacillus delbrueckii subspp. Bulgaricus 281 except (Cefpodoxime) and Lactobacillus casei 297 showed resistance to all the antibiotic discs tested. Lactobacillus fermentum 156 showed resistance to the all the antibiotic discs tested except Ampicillin, Ciprofloxacin and Cefpodoxime, whereas Lactobacillus rhamnosus 18 (except Nalidixic acid, Co-Trimoxazole and Ciprofloxacin) showed sensitivity to all the antibiotic discs tested (Table-3). The strains of Lactobacillus fermentum 141 and Lactobacillus plantarum 20 have shown resistance to Ampicillin, Nalidixic acid, Gentamicin and CoTrimoxazole, similar results were observed by [17]. But [18] observed that these three strains exhibited sensitivity to Ampicillin and Gentamicin under similar conditions. [6] reported that L. plantarum 20 and $L$. rhamnosus 18 showed resistance to Ampicillin, Nalidixic acid, Co-Trimoxazole, Gentamicin and Tetracycline and these findings are in accordance with the results of the present study except L. rhamosus 18 which was susceptible to Ampicillin, Gentamicin and Tetracycline.

Lactobacillus species has shown sensitivity to Cefpodoxime and Gentamicin, whereas resistance to almost all the antibiotic discs tested similar findings were revealed by [19] stated that all the lactic acid bacterial strains exhibited resistance to different antibiotic discs could be due to their natural and intrinsic resistance and might be due to the cell wall structure and membrane impermeability of LAB strains. In the present study, Lactobacillus casei 297 showed resistance to all the antibiotics discs tested. Among six LAB's tested, five showed susceptibility to some of the antibiotic discs tested. The susceptibility might be due to their broad antibacterial spectrum and excellent safety profile [20].

Antibacterial activity: All the six lactic acid bacterial strains showed good antibacterial activity (Table-4) against the tested pathogenic bacteria namely,
Staphylococcus aureus, Salmonella paratyphi B, E.coli ATCC and Pseudomonas spp. Lactobacillus delbrueckii subspp. Bulgaricus 281, Lactobacillus casei 297 and Lactobacillus fermentum 141 inhibited the all the pathogenic bacteria used in the study, whereas Lactobacillus fermentum 156 showed resistance to Staphylococcus aureus and E.coli ATCC whereas susceptibility to the Salmonella paratyphi $B$ and Pseudomonas spp. The total six LAB strains used in the study have shown good antagonistic activity against different food borne pathogens with varying degree of zone of inhibition. Among six LAB's, Lactobacillus delbruckii subspp. Bulgaricus 281, Lactobacillus casei and Lactobacillus fermentum 141 inhibited the all the pathogenic bacteria in vitro. [18] reported that the antibacterial action of four strains of L. fermentum, L. plantarum, L. casei and L. brevi which inhibited the growth of E.coli, Staphylococcus aureus, Klebsialla spp and Pseudomonas spp. They also observed slight differences in antagonistic activity of LAB's on tested pathogenic organisms due to production of antimicrobial compounds to varying degree. The increase in the production of lactic acid with time has been attributed to lowered $\mathrm{pH}$, which permits the growth of LAB. The antimicrobial effect of lactic acid is due to undissociated form of acid, which penetrates the membrane and liberates hydrogen ion in the neutral cytoplasm thus leading to inhibition of vital cell functions. Lactic acid bacterial strains used in the study have exhibited good antibacterial activity against the food borne pathogens tested and the results are in agreement with the findings of the [21]. Antibacterial activity of LAB on enteric pathogenic bacteria viz, $S$. aureus and E.coli are in accordance with [22]. Good antibacterial activity was shown against all the pathogens used in the study by L. delbrueckii subspp. bulgaricus 281 which was similar to the findings of [23]. Among all the strains L. plantarum 20 and $L$. rhamnosus 18 showed strong antibacterial activity against all the enteric pathogens tested and similar results were observed by [6]. This might be due to the production of acetic and lactic acids that lower the $\mathrm{pH}$ 
of the medium or may be due to competition for nutrients or may be due to production of bacteriocin or other antibacterial compounds.

\section{Conclusion}

From the present study it could be concluded that Lactobacillus fermentum 141 and Lactobacillus casei 297 had good probiotic characteristics in terms of acid tolerance, bile tolerance, antibiotic sensitivity and antibacterial activity against different pathogens and could be used as potential functional probiotics in the food and dairy industry for commercial use.

\section{Authors' contributions}

BS: Done the research and drafted the manuscript. TMR: Advisor during the research and revised the manuscript. PVMR: Research associate of the project and helped during the research. KKR: Principal investigator of the project and main advisor during the research.

\section{Acknowledgements}

The authors are thankful to Department of Biotechnology, Government of India, New Delhi for providing funding (BT/PR-14774/FNS/20/470/2010) dated 11/02/2011 to carry out the research work.

\section{Competing interests}

The authors declare that they have no competing interests.

\section{References}

1. Possemiers, S, Grootaert, C, Vermeiren, J, Gross, G, Marzorati, M. and Verstraete W. (2009) The intestinal environment in health and disease recent insights on the potential of intestinal bacteria to influence human health. Current Pharmaceutical Design, 15:2051-65.

2. Packey, C.D. and Sartor, R.B. (2009) Commensal bacteria, traditional and opportunistic pathogens, dysbiosis and bacterial killing in inflammatory bowel diseases. Current Opinion in Infectious Diseases .22:292-301.

3. Spiller, R. and Garsed, K. (2009) Infection, inflammation, and the irritable bowel syndrome. Dig Liver Dis. 41(12): 844-849.

4. Cani, P.D. and Delzenne, N.M. (2009) The role of the gut microbiota in energy metabolismand metabolic disease. Current Pharmaceutical Design .15:1546-58.

5. Penders, J, Stobberingh, E.E, van den Brandt, P.A. and Thijs, C. (2007) The role of the intestinal microbiota in the development of atopic disorders. Allergy; 62:1223-36.

6. Tambekar, D. H. and Bhutada, S. A. (2010) An evaluation of probiotic potential of Lactobacillus sp. From Milk of domestic animals and commercial available probiotic Preparations in prevention of enteric bacterial infections. Recent Research. in Science. and Technology. 2: 82.

7. Halami, P.M., Chandrashekar, A. and Josephm, R. (1999) Characterization of bacteriocinogenic strains of lactic acid bacteria in fowl and fish intestines and mushroom. Food Biotechnology. 13: 121-136.

8. Bauer, A., Kirby, W. M. and Sherris, J. C. (1966)Antibiotic susceptibility testing by a single disc method. American Journal of Clinical Pathology. 45: 493-496.

9. Barefoot, S and Klaenhamme, T. R. (1984) Detection and Activity of Lactacin B, a Bacteriocin Produced by Lactobacillus acidophilus, Appl. and Environ. Microbiol., 45: 1808-1815.

10. Lee, Y. K. and Salminen, S. (1995) The coming age of probiotics Trends in food science. and Technology. 6:241.

11. Henriksson, R., Bergstrom, P., Frnzen, L., Lewin, F. and Wagenius, G. (1999) Aspects of reducing gastrointestinal adverse effets associated with radiotheraphy. Acta oncologica, 38:159.

12. Pennacchia, C., Ercolini, D., Blaiotta, G., Pepe, O., Mauriello, G. and Villani, F. (2004) Selection of Lactobacillus strains from fermented sausages for their potential use as probiotics. Meat Science. 67:309.

13. Buntin, N., Suphitchaya, Chanthachum and Tipparat, Hongpattarakere. (2008) Screening of lactic acid bacteria from gastrointestinal tracts of marine fish for their potential use as probiotics. Songklanakarin Journol of Science and Technology. 30:141-148.

14. Dardir, H.A. (2012) In vitro Evaluation of Probiotic Activities of Lactic Acid Bacteria Strains Isolated From Novel Probiotic Dairy Products. Global Veterinaria, 8: 190-196.

15. Barakat, O. S., Ibrahim, G. A., Tawfik, N. F., El-kholy, W. I. and Gad el-rab, D. A. (2011) identification and probiotic characteristics of lactobacillus Strains isolated from traditional domiati cheese. International. Journol of Microbiological Research. 3:59-66.

16. Shukla, G., Sharma, G. and Goyal, N. (2010) Probiotic Characterization of Lactobacilli and Yeast Strains Isolated from Whey Beverage and Therapeutic Potential of Lactobacillus Yoghurt in Murine Giardiasis. American Journol of Biomedical. Science. 2: 248.

17. Patil, M. M. Pal, A., Anand, T. and Ramana, K. V. (2010) Isolation and identification of lactic acid bacteria from curd and cucumber Indian Journal of Biotechnology. 9:166.

18. Saranya, S. and Hemashenpagam, N. (2011) Antagonistic activity and antibiotic sensitivity of Lactic acid bacteria from fermented dairy products. Advances in Applied Science and Research. 2:528.

19. Sieladie, D. V., Zambou, N. F., Kaktcham, P.M., Cresci, A. and Fonteh, F. (2011) Probiotic properties of lactobacilli strains isolated From raw cow milk in the western highlands of Cameroon. Innovative Romanian Food Biotechnology. 9: 12.

20. Yu, Z., Xue Zhang, Sheng-yu, Li Chang-ying, Li Da Li and Zhen-nai Yang. (2012) In vitro evaluation of probiotic properties of Lactobacillus plantarum strains isolated from Chinese Sauerkraut. African Journal of Biotechnology. 11: 4868.

21. Al-Allaf M. A. H., Al-Rawi A. M. M and Al-Mola, A. T. (2009) Antimicrobial activity of lactic acid bacteria isolated from minced beef meat against some pathogenic bacteria. Iraqi Journal of Veterinary Science. 23:115-117.

22. Sarkono, Faturrahman and Yayan, Sofyan (2010) Isolation and identification of lactic acid bacteria from abalone (Haliotis asinina) as a potential candidate of probiotic. Journal ofBiosciences. 2:38.

23. Gawad, E. I. A., Fatah, E. A. M. and Al Rubayyi, K.A. (2010) Aspects of invitro and invivo research approaches directed towards identifying probiotics and prebiotics for human use. Journal of American Sciences. 6 (10): 156-159.

24. CLSI (2007) Performance standards for antimicrobial susceptibility; seventeenth Informational supplement. 27(1): M100-S17. 